$\underline{\text { Reports }}$

\title{
Community-driven data revolution is feasible in developing countries: experiences from an integrated health information and surveillance system in Kenya
}

\author{
Anthony K Ngugi', Gijs Walraven ${ }^{2}$, James Orwa ${ }^{1}$, Adelaide Lusambili', Maureen Kimani ${ }^{3}$, Stanley Luchters ${ }^{4}$ \\ ${ }^{1}$ Department of Population Health, Aga Khan University, Nairobi, Kenya, ${ }^{2}$ Aga Khan Development Network, Geneva, Switzerland, ${ }^{3}$ Division of \\ Community Health, Ministry of Health, Nairobi, Kenya, ${ }^{4}$ Department of Population Health, Aga Khan University, Nairobi, Kenya; International Centre \\ for Reproductive Health, Department of Public Health and Primary Care, Ghent University, Belgium; Department of Epidemiology and Preventive \\ Medicine, Monash University, Australia; Burnet Institute, Melbourne, Australia \\ Keywords: health information, community health surveillance, community health workers \\ https://doi.org/10.29392/001c.25977
}

\section{Journal of Global Health Reports}

Vol. 5, 2021

Over the period of the Millennium Development Goals (2000-15), it became clear that there was a pressing need and an increasing capacity for a 'data revolution' to inform the global health development agenda. In most developing countries, data on key indicators were collected through laborious and retrospective surveys that were as much as five years out-of-date, or through passive reporting systems that relied on routinely generated health facility data. Gaps in the primary data were filled by modelled estimates, which often relied on inadequate assumptions.

Recognition of this gap led the United Nations to convene an International Expert Advisory Group on a Data Revolution for Sustainable Development. This group released the 'A World That Counts: Mobilising the Data Revolution for Sustainable Development' report which highlighted the need for better data and statistics to help governments track progress. ${ }^{1}$ The Sustainable Development Goals have been closely tied to the data revolution from their outset.

In many Low and Middle Income Countries (LMICs), health information and civil and vital statistics systems are underdeveloped. Most events such as births, morbidity and deaths also occur outside the reach of these systems and are as such not officially captured. ${ }^{2}$ Additionally, data collection, when done, is often inconsistent, quality is poor and most data remain unprocessed for use. ${ }^{3}$ Consequently, governments and healthcare organizations lack reliable systems for data collection, verification and aggregation ${ }^{4}$ as well as capacity for analyses, interpretation and dissemination to address health challenges. In rural and remote geographies that bear a disproportionately higher burden of poor health outcomes, obtaining credible data can be even more difficult due to constraints associated with extreme poverty, illiteracy, insecurity, poor infrastructure and skewed distribution of human and material resources. This lack of health information undermines evidence informed policy-making, program design, implementation, monitoring and service delivery, ${ }^{5}$ further exacerbating inequalities.

\section{THE NEED FOR SURVEILLANCE SYSTEMS AND PERIODIC HEALTH SURVEYS}

In high income settings, data from well-developed public health surveillance systems have been used to determine the burden of disease, identify risk factors and to inform immediate public health action and policy on conditions as diverse as Acute Flaccid Paralyses, childhood overweight and obesity, levels of physical activity, and sporting injuries among others. 6

To address the problem of poor civil registration systems in LMICs, governments and other stakeholders typically develop localized surveillance programs. These systems capture data from sample populations, which are used centrally to inform policy and programs. For example, some countries that have not achieved universal civil registration have implemented SAVVY (SAmple Vital registration with Verbal autopsY) to improve the quality of vital statistics. SAVVY addresses short- to medium-term needs for critical information on births, deaths, and cause of death at the population level. ${ }^{7}$ Other systems that capture information on both health and vital events on sample populations include Health and Demographic Surveillance Systems (HDSSs) established and operated by national public health institutes or institutions of higher learning. HDSSs also provide platforms for health and population research, generate regular population and health statistics and share data publicly to enhance their utility. ${ }^{8}$

In LMICs, the planning, implementation and evaluation of health programmes at central level is increasingly informed by periodic regional or national population surveys. These include population-level surveys such as the Demographic and Health Surveys, Multiple Cluster Indicator Surveys, AIDS Indicator Surveys and Malaria Indicator Surveys among others. On the other hand, planning for health service delivery is informed by facility based surveys such as the Service Availability and Readiness Assessments, and Service Provision Assessments. These surveys assess the actual service delivery infrastructure, capacity to provide services, and quality and quantity of services provided. ${ }^{9}$

\section{PROBLEMS WITH CURRENT DATA SYSTEMS IN LMICS}

Periodic population-level and health facility surveys are costly, usually rely on donor funding and are thus not locally sustainable. Data from these surveys may find utility at macro-level (global and or national) program planning and policy development. However, centralized planning 
could render these surveys insensitive to nuanced sub-national health system information needs. Implementation over large geographical areas (regional or national) could also mean that their indicator estimates often mask gross local area disparities. Furthermore, these surveys are implemented every three to five years and may be unresponsive to rapidly changing local area priorities. Consequently, these factors imply that these surveys have limited utility to local health systems and communities.

With advancement in technology and changes in systems of governance e.g. devolution of health services to sub-national level in Kenya, there is increased capacity and opportunity for a locally-oriented data revolution in which local health systems and communities generate and use their own data to plan, implement and evaluate their health programs. To contribute to the goal of universal health coverage and the SDG agenda, local health ecosystems must be strengthened to generate health information that addresses their own unique health priorities, that is more up to date, sustainable, readily accessible, easy to interpret and use locally, and which can potentially feed into national data platforms.

The Aga Khan University together with two local health authorities in the coastal area of Kenya developed a strategy to address these issues. This approach consists of a system to capture the demographic and health information of this area, nested on the government's community health strategy. ${ }^{10}$ The system, briefly described below, has dual aims which include (i) strengthening the capacity of the local department of health for collection, processing and use of population-level health and vital events data; and (ii) provide a platform serving the University's needs for population-level research and academic programming. In this viewpoint, we describe the development and utility of the system within the first aim, while its epidemiological utility in the second aim has been described elsewhere. ${ }^{11}$

\section{DESCRIPTION OF KALOLENI/RABAI COMMUNITY HEALTH AND DEMOGRAPHIC SURVEILLANCE SYSTEM (KRHDSS)}

Briefly, it consists of a biannually updated population and health information registry of approximately 92,000 residents in 18,337 households within 112 villages in the rural Kaloleni and Rabai sub-Counties in the Coastal Area of Kenya. This platform is nested on the Kenya government community health strategy and data are collected by community health volunteers (CHVs) during their routine health promotion and education activities in the households. The project team provides regular refresher training, quality control and supervision of household data collection by CHVs as well as supports the use of the data for community-level planning and mobilization of health activities. Since 2017, seven biannual rounds of electronic data collection have been completed, which capture information on about 40 demographic, health, social determinants of disease and vital events. The indicators and their definitions are based on the Ministry of Health household-level data collection tool, ${ }^{10}$ and can be adapted to local needs and priorities.
These data are archived electronically and households and residents are allocated unique IDs through which individual information is linked longitudinally across data collection rounds. These data are also accessible to the local department of health for planning of health interventions. ${ }^{11}$

The data are analyzed to produce reports of indicator estimates and trends. Aggregate data are shared with the health system management for decision-making and updating the health information system while data disaggregated by village or community health unit are discussed and shared with CHVs and community health officers for community-level feedback and activity planning during community health dialogues. The sequence of activities within a typical KRHDSS surveillance cycle is presented in Figure 1. To allow more in-depth exploration of social determinants of health in the local context, these data can also be linked with those form other sources e.g. geolocation linkage with data on physical infrastructure, climate and physical environment, population density, land use, mobile phone coverage and use among others.

\section{DEVELOPMENT OF COMMUNITY HEALTH UNITS, SELECTION AND TRAINING OF CHVS AND DATA COLLECTION.}

Development of this system involved consultations with community members, village and government administration and public health officials in the target areas. In these meetings, the purpose of the project was explained and the support sought from these stakeholders. Community health units were established and CHVs selected by the community members following the Ministry of Health guidelines. ${ }^{10}$ The selected CHVs in each community health unit were then trained on data collection by project and Ministry of Health personnel.

Refresher training is conducted at the beginning of each biannual data collection round. Trained $\mathrm{CHVs}$ are allocated between 50 and 100 households for data collection, during which each CHV is visited at least twice for supportive supervision. The estimated per capita cost of one biannual cycle is USD 0.82 and USD 4.12 per household.

\section{DATA INTERPRETATION, DISSEMINATION AND USE COMMUNITY LEVEL}

Interpretation of the results of data analyses include discussions between public health personnel, CHVs and the project team at the beginning of each refresher training session. It involves an indicator-by-indicator examination of estimates from the previous round and a review of the trends to the current round. Based on these discussions, the teams identify priority indicators for health promotion and education. They also receive a summary report of findings for community dissemination and to support their efforts to mobilize community health activities.

\section{DATA USE BY THE LOCAL DEPARTMENT OF HEALTH AND OTHER STAKEHOLDERS}

The local department of health is using these data in plan- 


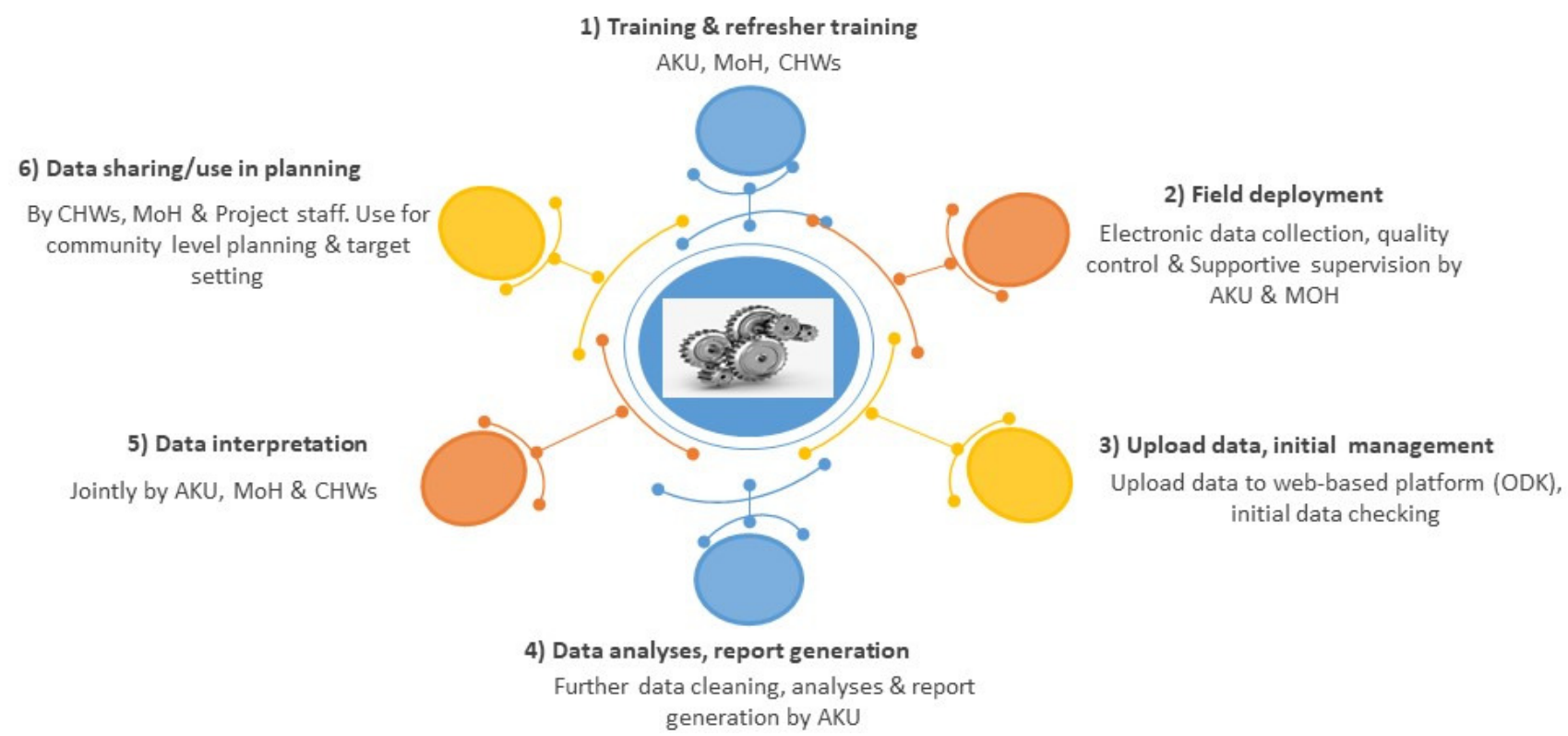

Figure 1. The Kaloleni-Rabai Health and Demographic Surveillance System (KRHDSS) cycle.

ning mobilization and outreach activities to villages with poor coverage or uptake of interventions. For example, villages with poor WaSH indicators have benefited from intensified mobilization and support for pit latrine construction and installation of handwashing facilities while those with low usage of insecticide treated nets are targeted during mass net distribution campaigns. The demographic and household membership data have also been used in filariasis eradication campaigns, defaulter tracing e.g. for immunizations, planning and budgeting for activities while the local administration has used them to guide planning for relief food distribution during drought. Additionally, the local public health officials have been extracting and synthesizing data summaries to update the community level health information system, thereby contributing to the $\mathrm{Na}$ tional Health Management Information System.

\section{WHAT HAS BEEN THE IMPACT?}

The engagement of CHVs in this program has enhanced their retention (over 94\% retained over the 3 years), increased contact with community and lead to enhancement of efforts in household and community-level health promotion and education and subsequently improvements in community health indicators.

This work demonstrates the feasibility of utilizing existing community health structures to collect locally relevant health information.

\section{WHAT ARE THE CHALLENGES?}

Challenges to establishing a successful community health surveillance platform relate to building and sustaining local community buy-in, shortage of literate local community resource persons who can be trained on collection and dissemination of health information using digital technologies and syncing with the needs of the local health system to ensure uptake at the official level. These can be mitigated by building relationships and trust with the local community and health system, over a period of time. This would entail ensuring community participation from the onset, for example, in identification of qualified local implementers, fostering local relevance of the program outputs through consultations with the local health system management in the initial phases and providing timely and useful feedback and results of analyses to inform health action.

\section{CONCLUSIONS}

The approach of integrated community-oriented health information system can mitigate challenges associated with traditional routine population data collection in underserved populations. Providing regular training opportunities and supportive supervision improves availability of quality data for informed decision making and planning. This model is inexpensive, replicable and scalable, strengthens local community-based health information systems and enhances the utilization of data for decision making at the local level. 
Table 1. Key indicators and their definitions within KRHDSS.

\begin{tabular}{|c|c|c|c|c|}
\hline & $\begin{array}{l}\text { Indicator/ } \\
\text { Variable }\end{array}$ & $\begin{array}{l}\text { Target } \\
\text { respondent(s) }\end{array}$ & Description/definition & Information collected \\
\hline 1 & Household & $\begin{array}{l}\text { All } \\
\text { households }\end{array}$ & One or several adjacent houses/dwellings that accommodate a nuclear family under the same household head & $\begin{array}{l}\text { Names of the hhh*, GPS } \\
\text { coordinates, and a unique } \\
\text { household id }\end{array}$ \\
\hline 2 & Membership & $\begin{array}{l}\text { All members } \\
\text { of a } \\
\text { household }\end{array}$ & A persons residing within a uniquely identified household. & $\begin{array}{l}\text { Names (3), date of birth, age, } \\
\text { sex, event (resident, died, } \\
\text { migrated, pregnant, newborn), } \\
\text { relationship to hhh. }\end{array}$ \\
\hline 3 & Orphanhood & $\begin{array}{l}\text { All children } \\
<18 \text { years old }\end{array}$ & A target hh† member whose one or both parents are deceased & Yes/No as per the definition \\
\hline 4 & $\begin{array}{l}\text { Birth } \\
\text { certification }\end{array}$ & $\begin{array}{l}\text { All members } \\
\text { of } \mathrm{HH}\end{array}$ & A target hh member whose birth is registered (ascertained by availing of a birth certificate to the interviewer) & Yes/No as per the definition \\
\hline 5 & Pregnancy & $\begin{array}{l}\text { All women } \\
>=12 \text { years of } \\
\text { age }\end{array}$ & A target hh member who is pregnant & Yes/No as per the definition \\
\hline 6 & Birth & All newborns & $\begin{array}{l}\text { A neonate/infant }<6 \text { months old born to a female member of a uniquely identified } \mathrm{HH} \text { in the interval since the } \\
\text { previous round of data collection }\end{array}$ & $\begin{array}{l}\text { Date of birth, name, sex, } \\
\text { relationship to hhh }\end{array}$ \\
\hline 7 & Death & $\begin{array}{l}\text { All members } \\
\text { of } \mathrm{HH}\end{array}$ & $\begin{array}{l}\text { A previously uniquely identified member of a } \mathrm{HH} \text { who is reported to have died in the interval since the last } \\
\text { round of data collection }\end{array}$ & $\begin{array}{l}\text { Yes/No as per the definition, } \\
\text { Date of death }\end{array}$ \\
\hline 8 & In-migration & $\begin{array}{l}\text { All new } \\
\text { members }\end{array}$ & $\begin{array}{l}\text { A previously unregistered persons that move into a previously uniquely identified } \mathrm{HH} \text { or into a newly } \\
\text { established } \mathrm{HH} \text { within the surveillance area and plan to stay for at least } 6 \text { months }\end{array}$ & Yes/No as per the definition \\
\hline 9 & Out-migration & $\begin{array}{l}\text { All } \mathrm{HH} \\
\text { members }\end{array}$ & $\begin{array}{l}\text { A previously uniquely identified persons that move out of a previously uniquely identified } \mathrm{HH} \text { or outside the } \\
\text { surveillance area and plan to stay away for at least } 6 \text { months }\end{array}$ & Yes/No as per the definition \\
\hline 10 & Schooling & $\begin{array}{l}\text { All Children } \\
6-18 \text { year old }\end{array}$ & A target hh member currently enrolled in a learning institution & Yes/No as per the definition \\
\hline 11 & $\begin{array}{l}\text { Ownership of } \\
\mathrm{MCH} \text { booklet }\end{array}$ & $\begin{array}{l}\text { Children }<5 \\
\text { years and } \\
\text { pregnant } \\
\text { women }\end{array}$ & A target hh member issued with the Maternal and Child Health $(\mathrm{MCH})$ booklet & Yes/No as per the definition \\
\hline 12 & $\begin{array}{l}\text { ANC 4+ } \\
\text { attendance }\end{array}$ & $\begin{array}{l}\text { All women } \\
\text { who gave } \\
\text { birth in the } \\
\text { previous } 11 \\
\text { months }\end{array}$ & A target hh member who attended at least 4 ante-natal care (ANC) clinics in the previous pregnancy & Yes/No as per the definition \\
\hline 13 & $\begin{array}{l}\text { Skilled Birth } \\
\text { Attendance }\end{array}$ & $\begin{array}{l}\text { All women } \\
\text { who gave } \\
\text { birth in the }\end{array}$ & A target hh member who gave birth either in a health facility or through the help of a skilled healthcare worker & Yes/No as per the definition \\
\hline
\end{tabular}




\begin{tabular}{|c|c|c|c|c|}
\hline & $\begin{array}{l}\text { Indicator/ } \\
\text { Variable }\end{array}$ & $\begin{array}{l}\text { Target } \\
\text { respondent(s) }\end{array}$ & Description/definition & Information collected \\
\hline & & $\begin{array}{l}\text { previous } 6 \\
\text { months }\end{array}$ & & \\
\hline 14 & $\begin{array}{l}\text { Exclusive } \\
\text { breastfeeding }\end{array}$ & $\begin{array}{l}\text { All children } \\
<6 \text { months of } \\
\text { age }\end{array}$ & A target hh member fed exclusively on breast milk & Yes/No as per the definition \\
\hline 15 & $\begin{array}{l}\text { Use of modern } \\
\text { family planning }\end{array}$ & $\begin{array}{l}\text { All women } \\
\text { aged 15-49 } \\
\text { years }\end{array}$ & A target hh member using any of the modern methods of family planning & Yes/No as per the definition \\
\hline 16 & $\begin{array}{l}\text { Pentavalent } 1 \\
\text { vaccination }\end{array}$ & $\begin{array}{l}\text { All children } \\
\text { aged } 6 \\
\text { weeks-11 } \\
\text { months }\end{array}$ & A target hh member who has received Pentavalent 1 vaccination & Yes/No as per the definition \\
\hline 17 & $\begin{array}{l}\text { Pentavalent } 3 \\
\text { immunization }\end{array}$ & $\begin{array}{l}\text { All children } \\
\text { aged } 14 \\
\text { weeks-11 } \\
\text { months }\end{array}$ & A target hh member who has received Pentavalent 3 vaccination & Yes/No as per the definition \\
\hline 18 & $\begin{array}{l}\text { Measles } \\
\text { immunization }\end{array}$ & $\begin{array}{l}\text { All children } \\
\text { aged 9-18 } \\
\text { months }\end{array}$ & A target hh member who has received Measles vaccination & Yes/No as per the definition \\
\hline 19 & $\begin{array}{l}\text { Vitamin A } \\
\text { supplementation }\end{array}$ & $\begin{array}{l}\text { All children } \\
\text { aged 6-59 } \\
\text { months }\end{array}$ & A target hh member who has received Vitamin A supplementation in the previous 6 months & Yes/No as per the definition \\
\hline 20 & $\begin{array}{l}\text { Complementary } \\
\text { feeding }\end{array}$ & $\begin{array}{l}\text { All children } \\
\text { aged 6-23 } \\
\text { months }\end{array}$ & A target hh member who has eaten food from all 3 main food groups in the last 24 hours & Yes/No as per the definition \\
\hline 21 & $\begin{array}{l}\text { Severe } \\
\text { malnutrition } \\
\text { (6-59 month } \\
\text { olds) }\end{array}$ & $\begin{array}{l}\text { All children } \\
\text { aged 6-59 } \\
\text { months }\end{array}$ & $\begin{array}{l}\text { A target hh member whose Mid-upper Arm Circumference (MUAC) measurement }<11 \mathrm{~cm} \text { (range marked red on } \\
\text { the MUAC tape) }\end{array}$ & Yes/No as per the definition \\
\hline 22 & $\begin{array}{l}\text { Moderate } \\
\text { malnutrition }\end{array}$ & $\begin{array}{l}\text { All children } \\
\text { aged 6-59 } \\
\text { months }\end{array}$ & $\begin{array}{l}\text { A target hh member whose MUAC measurement }>=11 \mathrm{~cm} \text { and }<=12.5 \mathrm{~cm} \text { (range marked yellow on the MUAC } \\
\text { tape) }\end{array}$ & Yes/No as per the definition \\
\hline 23 & $\begin{array}{l}\text { Use of Long } \\
\text { Lasting } \\
\text { Insecticide- } \\
\text { treated Nets } \\
\text { (LLINs) }\end{array}$ & $\begin{array}{l}\text { All members } \\
\text { of a } \\
\text { household }\end{array}$ & A target hh member who slept under a LLIN the night before the interview & Yes/No as per the definition \\
\hline 24 & Knowledge of & All members & A target hh member who tested for HIV in the last 6 months & Yes/No as per the definition \\
\hline
\end{tabular}




\begin{tabular}{|c|c|c|c|c|}
\hline & $\begin{array}{l}\text { Indicator/ } \\
\text { Variable }\end{array}$ & $\begin{array}{l}\text { Target } \\
\text { respondent(s) }\end{array}$ & Description/definition & Information collected \\
\hline & HIV status & $\begin{array}{l}\text { of a } \\
\text { household } \\
\text { aged }>6 \text { years }\end{array}$ & & \\
\hline 25 & $\begin{array}{l}\text { Access to safe } \\
\text { water }\end{array}$ & $\begin{array}{l}\text { All } \\
\text { households }\end{array}$ & $\begin{array}{l}\text { A target hh that source water for drinking or hh use from either piped water into dwelling, piped water to yard/ } \\
\text { plot, public tap or standpipe, borehole, Protected dug well, protected spring, bottled water, or harvested } \\
\text { rainwater }\end{array}$ & Yes/No as per the definition \\
\hline 26 & $\begin{array}{l}\text { Treatment of } \\
\text { drinking water }\end{array}$ & $\begin{array}{l}\text { All } \\
\text { households }\end{array}$ & $\begin{array}{l}\text { A target hh that treat drinking water by either boiling, adding bleach/chlorine, use a water filter (electrical, } \\
\text { ceramic, sand, composite), or solar disinfection }\end{array}$ & Yes/No as per the definition \\
\hline 27 & $\begin{array}{l}\text { Ownership of } \\
\text { handwashing } \\
\text { equipment }\end{array}$ & $\begin{array}{l}\text { All } \\
\text { households }\end{array}$ & $\begin{array}{l}\text { A target hh that owns/has access to hand washing facilities that use running water e.g. tippy-tap, leaky tin, } \\
\text { piped water sink }\end{array}$ & Yes/No as per the definition \\
\hline 28 & $\begin{array}{l}\text { Ownership of a } \\
\text { functional } \\
\text { latrine }\end{array}$ & $\begin{array}{l}\text { All } \\
\text { households }\end{array}$ & $\begin{array}{l}\text { A target hh that owns/has access to the following types of sanitation facilities: flush to piped sewer system; } \\
\text { flush to septic tank; flush/pour flush to pit; composting toilet; VIP latrine; pit latrine with(out) a slab with an } \\
\text { added assessment of functionality (clear path to the toilet, not in a bushy isolated area, smell, offering privacy } \\
\text { etc) }\end{array}$ & Yes/No as per the definition \\
\hline 29 & $\begin{array}{l}\text { Ownership of } \\
\text { refuse a disposal } \\
\text { facility }\end{array}$ & $\begin{array}{l}\text { All } \\
\text { households }\end{array}$ & $\begin{array}{l}\text { A target hh that has owns/shares the following types of sanitation facilities: waste disposal bin, pit, or disposes } \\
\text { waste by burning }\end{array}$ & Yes/No as per the definition \\
\hline
\end{tabular}

Key: " household, † household head 


\section{CONFLICTS OF INTEREST}

\section{ACKNOWLEDGEMENTS}

The Community and Community Health Volunteers whose involvement and work is highlighted in this viewpoint.

\section{FUNDING}

None.

\section{AUTHORSHIP CONTRIBUTIONS}

AKN and SL conceived the idea presented in this manuscript. The first author developed the first draft and all authors contributed to editing and finalizing the write-up.
The authors completed the ICMJE Unified Competing Interest form on http://www.icmje.org/disclosure-of-interest/ (available upon request from the corresponding author), and declare no conflicts of interest.

\section{CORRESPONDENCE TO:}

Anthony K Ngugi (PhD, DLSHTM), Department of Population Health, Medical College (East Africa).

Aga Khan University, Nairobi, Kenya. anthony.ngugi@aku.edu

Submitted: June 29, 2021 GMT, Accepted: July 08, 2021 GMT 


\section{REFERENCES}

1. UN Secretary-General's Independent Expert Advisory Group on the Data Revolution for Sustainable Development. A World That Counts Mobilising the Data Revolution for Sustainable Development. United Nations; 2014.

2. Setel PW, Sankoh O, Rao C, et al. Sample registration of vital events with verbal autopsy: a renewed commitment to measuring and monitoring vital statistics. Bull World Health Organ. 2005;83(8):611-617.

3. Ndabarora E, Chipps J, Uys L. Systematic review of health data quality management and best practices at community and district levels in LMIC. Information Development. 2014;30:103-120.

4. Bram JT, Warwick-Clark B, Obeysekare E, Mehta K. Utilization and Monetization of Healthcare Data in Developing Countries. Big Data. 2015;3(2):59-66. do i:10.1089/big.2014.0053

5. Health Data Collaborative. Data for health and sustainable development. Published online 2020. Accessed September 16, 2020. https://www.healthdat acollaborative.org/

6. Groseclose SL, Buckeridge DL. Public Health Surveillance Systems: Recent Advances in Their Use and Evaluation. Annu Rev Public Health.

2017;38:57-79. doi:10.1146/annurev-publhealth-0318 $\underline{16-044348}$
7. MEASURE Evaluation. Sample Vital Registration with Verbal Autopsy (SAVVY): An Overview. Published online 2007. Accessed September 9, 2020. $\underline{\mathrm{h}}$ ttps://www.measureevaluation.org/resources/publicat ions/ms-07-26-ob

8. INDEPTH Network. INDEPTH Network: Better Health Information for Better Health Policy. Published online 2020. Accessed September 12, 2020. http://www.indepth-network.org/

9. MEASURE Evaluation. Health Facility Assessment Methods. Published online 2020. Accessed September 9, 2020. https://www.measureevaluation.org/resource s/tools/health-information-systems/hfa-methods

10. Ministry of Health. Taking the Kenya Essential Package for Health to the community: a strategy for the delivery of level one services. In: Division of Community Services. ; 2006.

11. Ngugi AK, Odhiambo R, Agoi F, et al. Cohort Profile: The Kaloleni/Rabai Community Health and Demographic Surveillance System. Int J Epidemiol. 2020;49(3):758-759e. doi:10.1093/ije/dyz252 